

\title{
Introduction
}

\section{Kristeva and Race}

\author{
Carol Mastrangelo Bové \\ University of Pittsburgh
}

I mourn our Jewish neighbors murdered October 27"', 2018 at Tree of Life Synagogue, Pittsburgh. This forum is dedicated to them. I urge my audience to join in actions that dispel ignorance, combat hate, and promote the equality of all.

The Kristeva Circle Conference of 2017 in Pittsburgh confirmed that writers throughout the world have been engaging with Julia Kristeva's thought in large numbers and in ways relevant to "an ethics of inclusion," the topic of the Conference. A feeling of excitement was in the air at the event, particularly around the keynote speakers, Hortense Spillers and Jack Halberstam, and Kristeva herself, whose work has been an important influence on their own (Spillers's Black, White, and in Color and Halberstam's Skin Shows, for example).

The question of race arguably came to a head at the conference when one of the founders of the Kristeva Circle, Fanny Söderbäck, commented on the paper just delivered by Kristeva via Skype, "The Psychic Life--A Life in Time: Psychoanalysis and Culture." According to Söderbäck, we run the risk of reinforcing Islamophobic views that equate terrorism with Islam if we focus on young women intent on jihad without simultaneously addressing the behavior of white men bent on white supremacist violence and terrorism. Kristeva did not directly address the issue of her lecture's reinforcement of Islamophobic views in her response. Instead, she spoke at some length about a patient whose confrontation with Arabic poetry led to improvement in her psychic health.

I introduce the following papers in part as a dialogue with Kristeva on race and as a response to Söderbäck's comments. The essays explore many topics in light of her version of psychoanalysis, for example, AfricanAmerican writing, Puerto-Rican poetry and art, auto-destructive and 
Algerian art, Iraqi fiction, and Jihadism--an impressive, varied list. All make reference to questions of race and ethnicity in Kristeva's work. They do so in ways that provoke thought on the contributions of psychoanalytic writing, appreciated and also criticized for its universalizing tendencies, which may in part explain its vulnerability to charges of racism.

Jack Halberstam's article is an elaboration of the idea of "the wild" in his work, drawing on Kristeva's theories of the abject and the "malady of the soul." He focuses on auto-destructive art and the ways in which it disturbs and makes us think about the crises of the contemporary world characterized by destruction and the imminent end of the human. Deriving from the German artist Gustav Metzger's work, auto-destructive art as I understand it via Halberstam, asks, "Is it better to engage in destruction, rather than to continue to be part of a corrupt world bent on the annihilation of human beings?" Halberstam enables us to consider the theoretical framework Kristeva's theories provide for the examination of normative practices and the symbolic order that exclude, for example, people of color. The abject and the early separation from the mother are formative, human experiences to which we respond as individuals and in groups shaped by the symbolic order we have created. This order, primarily patriarchal and rationalist, often devalues others, that is, those who are not white heterosexual men, and in the process increasingly destroys what characterizes us as human beings, according to Halberstam.

The theory of the maternal central to Kristeva's thought appears as well in Benigno Trigo's "From Necrotic to Apoptotic Debt: Using Kristeva to Think Differently about Puerto Rico's Bankruptcy." Trigo provides a detailed examination of her idea of the maternal hold, linking biology and psychology. Briefly put, at the end of her complex company with the child, the mother confronts death in separating from the infant. Some of the best artists, including Eduardo Lalo, recreate that confrontation in their work, in this case, his poetry, the photograph Adònica and Diego, and the drawing The Madonna of the Necrópolis. Seeing these works of art in this context enables one to understand more adequately Puerto Rico's struggle for liberation, its resilience as the oldest colony in the world. Appearing to have little to do with race, Trigo's essay implies that racism, including the internalization of racist attitudes by people of color, cultivates a version of arrested development in their view of colonial subjects and thus impedes that struggle. Trigo focuses in particular on the question of its national debt and the need for Puerto Rico to accept that burden in the spirit of the self-reliance deriving from confrontation with separation from the mother and with death, in its earliest version. His essay understands the debt in a bio-cultural context and argues for an approach to the problem on the model of Kristeva's for-giving maternal hold in an attempt to decrease radicalization.

Hortense Spillers does speak directly about race, as one expects in this canonical critic of African-American literature and theory. The continuing 
murder of young African-American men by the police in the US is at the heart of her piece. She invokes Ta-Nehesi Coates's writing and his dialogue with James Baldwin as an example of the need for African-American authors to focus on subjectivity, including unconscious drives, in an effort to combat racism. Creative writers who express their singularity while at the same time engaging with the historical, material conditions that connect them to the community of other black writers are major players in a world in need of change. Parent-child relations and the effort to help enable the next generation to play a role in the struggle for liberation are central in Spillers's essay.

While she does not discuss Kristeva explicitly, there is a subtext of the theory of the abject and the maternal-discussed in her Black, White, and in Color--in the words "these homicidal impulses start up from first things that disappear into the obscure past of troubled relations between elders and the younger," citing Claude Meillassoux. She draws implicitly on Kristeva's thought in her disagreement with Frank Wilderson's Afro-Pessimism for his conclusion that subjecthood-subjectivity is uncertain, even non-existent. As I read Spillers on Wilderson, he believes that abjection characterizes black psyches. In other words, he remains focused on the historical, material condition that "whole masses are swallowed down the gullet" and that "the subject of "social death" has been barred from language. To envision a race of people without the ability to speak, cannibalized by whites, is to see them as abject, Spillers implies.

Rejecting Afro-Pessimism, she invokes the need to recreate, document, and bequeath black subjectivity as it has struggled to play itself out in the United States. Here the subtext of Kristeva's theory of the maternal and its nurturing of the next generation makes its presence felt. Spillers advocates "words [like those of Ta-Nahesi Coates] that travel between fathers and sons and mothers and daughters on the vertical axis of the transfer of power and authority," as an antidote to "the long red record of violence" and the "intramural violence at unfathomable levels of repetition and mindlessness." She returns to her title in concluding that this voyage would be "nothing less than a perception of time and crisis."

William Scott also treats the question of African-American subjectivity that Spillers addresses. Scott builds on Kristeva's idea of the genotext in his linguistic examination of the form and content of Harryette Mullen's "Sapphire's Lyre Styles." He demonstrates how the poem voices the AfricanAmerican woman's attempt to liberate herself via her writing. The connection to race in Scott's essay is clear: for him, Kristeva's idea of the genotext enables a more precise examination of the singular voices of writers confronting their difficult task given the legacy of slavery and the destructive effect of the diaspora. 
The other essays in this issue problematize psychoanalytic theory in its connections to race by discussing the political implications of Kristeva's writing on Islam. Focusing primarily on Kristeva's "The Body of Adel" and Teresa, My Love, Elaine Miller raises the question of the same sort of racist element in Kristeva's writing that had surfaced earlier, for example, in Gayatri Spivak's critique of About Chinese Women. Is there a European, that is, white Christian bias in Kristeva's neglect of the need for a political space in her theory of the semiotic?

Frances Restuccia's “Kristeva's Severed Head in Iraq: Antoon's The Corpse Washer" begins carefully and slowly to tease out the ambiguities in her theory on images of decapitation, castration, and the maternal. She then launches into an analysis of Sinan Antoon's novel and, as in her incisive study of David Lynch's film Mulholland Drive elsewhere, demonstrates how a compelling questioning of violence and art emerges in certain texts when examined in the context of Kristeva's theory, in this case, in The Corpse Washer and its image of the severed head. Restuccia's conclusion probes the contributions of Kristeva's writing to the debates on psychoanalysis and Islam and demonstrates the abiding relevance of psychoanalytic thought to relations with "the foreigner" both within and without.

My own essay, "Spain and Islam Once More," a new paper which was not presented at the conference, reads Julia Kristeva's Teresa, My Love, her biographical novel on Saint Teresa of Avila. The essay demonstrates the ways in which, for Kristeva, Western rationalism, in its denial of the functions of the body, shapes language that is sexist, masochistic, and more likely to unleash the death drive than to channel Eros.

Her autobiographical narrator, Sylvia Leclercq, develops a theory resembling the author's own on the symbolic and semiotic poles of language, which, as we know, enables thought and gives a voice to the human spirit. Sylvia does this as she researches the life of Saint Teresa who grapples with bodily experience well before René Descartes, the source of much of the rationalist tendency of Western cultures. Teresa's mysticism, in its attempt to unite with God and to give rein to passion, is not without a resemblance to forms of fundamentalism, which may lead to terrorism. Instead of denying the body, Teresa places it front and center, thus laying herself open to the attacks of the Inquisition.

Teresa, My Love is able to show how maintaining a balance between the symbolic and semiotic aspects of language enables Teresa to control violence against herself and others. Kristeva demonstrates that Teresa's ability to "open a space" within herself, to transform her desire for a human Christ into a literary text, is a model for citizens intent on building a more peaceful and, in the context of the theme of Kristeva and race, a less racist world.

Like Teresa, My Love, Kristeva's keynote lecture, “The Psychic Life: A Life in Time," which I translated along with Anne Marsella, discusses at some 
length the psychoanalysis of radicals bent on jihad, the topic eliciting Söderbäck's question and comments. She believes the death drive leading some of her patients to suicidal behavior is a malady which analysis can help treat. Does Kristeva's theory and analysis neglect cultural difference and impose French ideals on the young Muslims? Is her attitude toward these patients vulnerable to the charge of racism?

Kristeva's essay, both philosophical and personal, provides the context for such questions. It contributes a brilliant genealogy of her psychoanalytic theory, including such key concepts as the abject, "the need to believe" and "the desire to know," with special focus on the contemporary experience of time. She offers a compelling argument that psychoanalysis is especially suited to help confront the problems we face, notably violence and psychic disorders, as 2018 comes to a frightening close. 